technologies to improve health care service delivery processes: a systematic review and meta-analysis. PLoS Med, 10 (1), 126. doi: 10.1371/journal.pmed.1001363

7. Inokuchi, R., Sato, H., Nakamura, K., Aoki, Y., Shinohara, K., Gunshin, M. et al. (2014). Motivations and barriers to implementing electronic health records and ED information systems in Japan. The American Journal of Emergency Medicine, 32 (7), 725-730. doi: 10.1016/j.ajem.2014.03.035

8. Lee, J., Kuo, Y., Goodwin, J. S. (2013). The effect of electronic medical record adoption on outcomes in US hospitals. BMC Health Services Research., 13 (1), 1-39. doi: 10.1186/1472-6963-13-39

9. Kim, Y., Kim, S. S., Kang, S., Kim, K., Kim, J. (2014). Development of mobile platform integrated with existing electronic medical records. Healthcare Informatics Research, 20 (3), 231-235. doi: 10.4258/hir.2014.20.3.231

10. Fiks, A. G., Grundmeier, R. W., Margolis, B., Bell, L. M., Steffes, J., Massey, J. et al. (2012). Comparative effectiveness research using the electronic medical record: an emerging area of investigation in pediatric primary care. The Journal of Pediatrics, 160, 719-724. doi: 10.1016/j.jpeds.2012.01.039

11. Schreiweis, B., Trinczek, B., Köpcke, F., Leusch, T., Majeed, R. W., Wenk, J. et al. (2014). Comparison of electronic health record system functionalities to support the patient recruitment process in clinical trials. International Journal of Medical Informatics, 83 (11), 860-868. doi: 10.1016/j.ijmedinf.2014.08.005

12. Middleton, B., Bloomrosen, M., Dente, M., Hashmat, B., Koppel, R., Overhage, J. M. et al. (2013). Enhancing patient safety and quality of care by improving the usability of electronic health record systems: recommendations from AMIA. Journal of the American Medical Informatics Association, 20 (1), 2-8. doi: 10.1136/amiajnl-2012-001458

13. Janols, R., Lind, T., Göransson, B., Sandblad, B. (2014). Evaluation of user adoption during three module deployments of region-wide electronic patient record systems. International Journal of Medical Informatics, 83 (6), 438-449. doi: 10.1016/j.ijmedinf.2014.02.003

14. Jardim, S. V. B. (2013). The Electronic Health Record and its contribution to healthcare information systems interoperability. Procedia Technology, 9, 940-948. doi: 10.1016/j.protcy.2013.12.105

15. Tully, M. P., Kettis, A., Höglund, A. T., Mörlin, C., Schwan, A., Ljungberg, C. (2013). Transfer of data or recreation of knowledge - experiences of a shared electronic patient medical records system. Research in Social and Administrative Pharmacy, 9 (6), 965-974. doi: 10.1016/j.sapharm.2013.02.004

16. Accenture, Overview of International EMR/EHR Markets (2010). Results from a Survey of Leading Health Care Companies. Available at: http://www.accenture.com/auen/Pages/insight -electronic-medical-record-surveysummary.aspx. 2010.

17. Pettit, L. (2013). Understanding EMRAM and how it can be used by policy-makers, hospital CIOs and their IT teams. World Hosp Heal Serv, 49, 7-10.

18. HIMSS Analytics. Available form: http://www.himssanalytics.eu (Last accessed: 07.12.2014).

19. HIMSS Analytics. Available at: http://www.himssanalytics.eu/sites/default/files/HAE_EMRAM _Overview_Stages_2012.pdf(Last accessed: 07.12.2014)

20. HIMSS Analytics. Available at: http://66.77.252.42/2013/general/emram.aspx (Last accessed: $07.12 .2014)$

Karlińska Maria, Assistant Professor, Doctor of Medical Sciences, Department of Medical Informatics and Telemedicine, Medical University of Warsaw, Żwirki i Wigury, 61, Warsaw, Poland, 02-091

E-mail: m.karlinska@gmail.com

УДК 616.216.1-002-085-003.6-078-035

DOI: 10.15587/2313-8416.2014.33716

\title{
ОБОСНОВАНИЕ ВЫБОРА МЕТОДА ЛЕЧЕНИЯ ЯТРОГЕННОГО ГАЙМОРИТА В ЗАВИСИМОСТИ ОТ ПРИРОДЫ ИНОРОДНОГО ТЕЛА И МИКРОБНОЙ АССОЦИАЦИИ
}

\section{(C) А. Г. Гулюк, С. Д. Варжапетян, А. Э. Тащян}

Выявлены особенности микробной флоры, степени обсемененности, а также изменений слизистой оболочки гайморовых пазух в зависимости от природы инородного тела в просвете синуса. На основании полученных результатов исследования клинического материала гайморовых пазух 45 больных хроническим верхнечелюстным синуситом определен объем лечебньх мероприятий 6 зависимости от природы инородного тела в просвете пазухи

Ключевые слова: хронический гайморит, инородное тело, морфология, обсемененность, микрофлора, хирургическое лечение, ятрогения

It is determined the features of the microbial flora, the degree of contamination, as well as changes in the mucous membrane of the maxillary sinuses, depending on the nature of the foreign body in the lumen of the sinus. Based on the results of microbiological and histological examination of clinical material of maxillary sinuses of 45 patients with chronic maxillary sinusitis is defined scope of therapeutic measures depending on the nature of a foreign body in the lumen of the sinus

Keywords: chronic sinusitis, foreign body, morphology, contamination, microflora, surgical treatment, iatrogenesis 


\section{1. Введение}

Лечение одонтогенного воспаления верхнеечелюстных пазух одна из основных проблем стоматологии [1-6]. Данная задача приобретает особую актуальность в условиях увеличения числа хронических форм гайморита, возникших вследствие попадания инородных тел различного происхождения в просвет верхнечелюстного синуса [7-11]

Одним из основных лечебных мероприятий при одонтогенных синуситах являются антибактериальная терапия и хирургическое удаление патологически измененной слизистой и инородных тел из гайморовой пазухи [7, 12-15]. Воздействие на патогенную микробную флору, как одну из основных звеньев лечения, обусловлено ролью микроорганизмов и бактерий в патогенезе развития хронического гайморита $[13,16,17]$. В свою очередь, неадекватная антибактериальная терапия может привести к развитию местного дисбиоза и иммунодефициту, создавая предпосылки к бессимптомному течению и рецидиву болезни [18].

Объем оперативных вмешательств на верхнечелюстной пазухе при ятрогенных гайморитах не всегда сопоставим с тяжестью патологии. Чрезмерная хирургическая травма может привести к индуцированию иммунодефицитных состояний в организме [14], а неоправданно щадящая тактика, выбранная хирургом при удалении инородных тел из верхнечелюстного синуса - причиной недостаточной его санации.

В данных условиях разработка комплекса лечебных мероприятий, сочетающих ревизию пазухи и медикаментозную терапию, является важной задачей в помощи больным с осложнениями в виде верхнечелюстного синусита, вызванного инородными телами различного происхождения [9].

Цель исследования: обосновать выбор метода комплексного лечения хронических ятрогенных гайморитов на основании результатов микробиологических и морфологических исследований.

\section{2. Литературный обзор}

До настоящего времени ведется активная полемика по поводу поиска наилучшей методики для оказания хирургической помощи больным с одонтогенными верхнечелюстными синуситами, вызванными попаданием инородных тел во время стоматологических вмешательств [19].

Несмотря на достаточную распространенность осложнений после стоматологических манипуляций, знание морфологических изменений слизистой оболочки и микробного состава гайморовой пазухи [20-22], механизмы развития воспаления в верхнечелюстном синусе при попадании в его просвет инородного тела до сих пор остаются неизвестными [21]. Некоторые авторы предполагают, что корневой герметик вызывает раздражение слизистой оболочки, нарушает мукоциллиарный клиренс, что способствует присоединению вторичной инфекции [22].

Имеющиеся в литературе данные, касающиеся лечения данной патологии, направлены, в основном, на поиск оптимальной и малоинвазивной техники оперативного вмешательства [23]. Проведенный анализ показал, что методом выбора для удаления инородных тел из верхнечелюстных пазух на сегодняшний момент должна быть эндоскопическая синусотомия [24-26]. А оптимальным методом рентгенологической диагностики - конусно - лучевая компьютерная томография [27, 28].

Наш клинический опыт указывает на зависимость выраженности клинических симптомов одонтогенного гайморита от наличия или отсутствия инородного тела в его просвете, а также от характера и происхождения этого тела. В научной литературе недостаточно публикаций, описывающих особенности течения патологических процессов в пазухе при различных формах одонтогенного и ятрогенного гайморита. Вопрос дифференциального подхода к комплексному лечению одонтогенных синуситов в зависимости от природы инородного тела в просвете пазухи до сих пор остается открытым.

\section{3. Материалы и методы}

Проведено микробиологическое и патоморфологическое исследования интраоперационного материала из верхнечелюстных пазух 45 больных (37,7 \% мужчин и $62,3 \%$ женщин) хроничес-ким ятрогенным гайморитом и инородным телом в синусе. У 22 (48,9 \%) наблюдаемых инородное тело в синусе было представлено пломбировочным материалом (корневой герметик), у 19 $(42,2 \%)$ - корнем зуба, у 4 (8,8 \%) - дентальным имплантатом.

Для предупреждения попадания детрита и погибших лейкоцитов в «посев» забор клинического материала из верхнечелюстных синусов, проводился после купирования острого воспаления в пазухе. За 24 часа до операции пациенты прекращали прием антибиотиков.

Предметом гистологического (морфологического) исследования послужил биопсийный материал слизистой оболочки гайморовой пазухи, который фиксировали в $10 \%$ растворе нейтрального формалина, обезвоживали в восходящей батарее спиртов, в качестве промежуточной среды использовали хлороформ, материал заливали в смесь воска-каучукапарафина $(1: 1: 20)$. Для обзорной микроскопии срезы окрашивали растворами гематоксилина и эозина. Выявление колоний грибов осуществляли в гистологических срезах, окрашенных по способу Грам-Вейгерта в модификации А. А. Боголепова.

Забор материала и его транспортировка для микробиологического исследования проводили со стенок верхнечелюстных пазух стерильными турундами стандартных пробирок для посева со средой Эймс. Для получения информации о количественном содержании микроорганизмов в отобранном материале использовали метод посева "тампон-петля" [29]. Для выделения анаэробов - 5 \% кровяной агар, агар с вареной кровью («шоколадный агар»). Для выделения аэробов использовали те же среды, плюс среда Эндо, среда Чистовича. Для выявления грибов рода Candida - среда Сабуро с хлорамтемиколом. Культивирование осуществляли в 
термостате при $37{ }^{\circ} \mathrm{C}$ в аэробных и анаэробных условиях с подсчетом колоний: через 24 и 48 часов инкубации - для аэробных микроорганизмов; через 48-72 часа - для анаэробных микроорганизмов; через 72-120 часов - для грибков рода Candida. Анаэробные условия создавали комплектом оборудования и расходных материалов (производитель bio Mérieux, Франция). Идентификацию выделенных аэробных культур и грибов проводили с использованием автоматического бактериологического анализатора "Vitek 2-compact" - производитель bio Mérieux (Франция), анаэробных культур - ручным методом с использованием набора API 20 E (bio Mérieux, Франция).

\section{4. Результаты исследования}

В результате проведенных исследований, в группах пациентов с инородными телами различного происхождения в просвете гайморовой пазухи были отмечены особенности в составе микробной флоры, степени обсемененности пазух и в характере морфологических изменений мембраны Шнайдера.

Из верхнечелюстных синусов с наличием в просвете пломбировочного материала (корневой герметик) в анаэробных условиях был выделен
Streptococcus intermedius (milleri группа) с показателем обсемененности $10^{8}$ КОЕ/тампон. В присутствии кислорода превалировали ассоциации аэробов с доминированием Streptococcaceae (44,5 \%) $10^{8} \mathrm{KOE} /$ тампон.

Из гайморовых пазух больных с незаконченным удалением зуба (наличие корня в гайморовой пазухе) в анаэробных условиях получен рост трех штаммов бактерий: в монокультуре высеян облигатный анаэроб Clostridium spp., в ассоциации с аэробами - ф. анаэробы Gemella morbilorum, Streptococcus intermedius, относящийся к комменсалам (нормальной микрофлоре) [20]. В аэробных условиях высеяны смешанные ассоциации с преобладанием бактерий рода Staphilococcaceae $(41,7 \%)$. Средний показатель обсемененности гайморовых пазух в данной группе был равен $10^{5} \mathrm{KOE/тампон.}$

При хроническом ятрогенном гайморите с наличием дентального имплантата в синусе в анаэробных условиях из посевов выделили монокультуру ф. анаэробного штамма Actinomyces israeli в непатогенной концентрации - $10^{3}$ КОЕ/тампон [31, 32, 33]. В аэробных условиях в $100 \%$ случаев высеян только штамм Moraxella catarrhalis $-10^{7} \mathrm{KOE} /$ тампон (табл. 1 ).

Таблица 1

Состав микробной флоры верхнечелюстных синусов при различных формах ятрогенного гайморита

\begin{tabular}{|c|c|c|c|}
\hline \multirow{2}{*}{$\begin{array}{c}\text { Тип инородного тела в } \\
\text { синусе }\end{array}$} & \multicolumn{2}{|c|}{ Микрофлора гайморовых пазух } & \multirow{2}{*}{$\begin{array}{c}\text { Средний показатель } \\
\text { обсемененности пазух }\end{array}$} \\
\hline & Анаэробы & Аэробы & \\
\hline $\begin{array}{c}\text { Пломбировочный материал } \\
\text { (герметик корневой) }\end{array}$ & $\begin{array}{l}\text { Streptococcus } \\
\text { intermedius }\end{array}$ & $\begin{array}{c}\text { Ассоциации аэробов, } \\
\text { с преобладанием } \\
\text { Streptococcaceae } \\
(44,5 \%) \\
\end{array}$ & $10^{8} \mathrm{KOE} /$ тампон \\
\hline Корень зуба & Clostridium spp. & $\begin{array}{c}\text { Смешанная флора, } \\
\text { с преобладанием } \\
\text { Staphilococсасеаe } \\
(41,7 \text { \%) }\end{array}$ & $10^{5} \mathrm{KOE} /$ тампон \\
\hline Имплантат & Actinomyces israeli & $\begin{array}{c}\text { Монокультура, } \\
\text { Moraxella (100\%) }\end{array}$ & $10^{4} \mathrm{KOE} /$ тампон \\
\hline
\end{tabular}

Гистологическое исследование показало, что хронический ятрогенный верхнечелюстной синусит, инициированный корневым герметиком, наиболее часто сопровождается фиброзом (в $91 \%$ случаев), некрозом (82 \%) и наличием колонии грибов $(36 \%)$ в слизистой оболочке пазухи (рис. 1, 2).

При ятрогенном гайморите с наличием отломка корня зуба в пазухе наиболее часто выявляли метаплазию (50 \%) и утолщение мембраны Шнайдера (66,7 \%) (рис. 3, 4).

В присутствие дентального имплантата в $100 \%$ случаев отмечена атрофия покровного эпителия гайморовой пазухи (рис. 5).

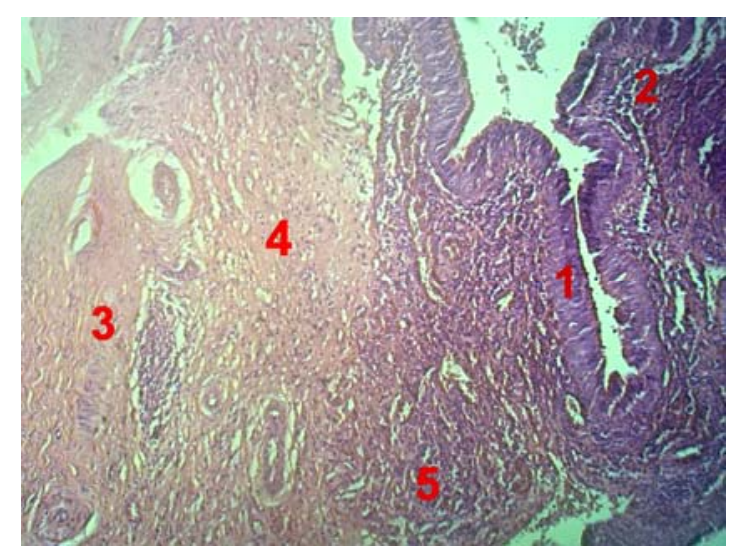

Рис. 1. Слизистая оболочка гайморовой пазухи больного хроническим ятрогенным гайморитом, вызванным эндогерметиком. Ок. х10, об. х40.

Окраска гематоксилином и эозином. 1 - эпителий, 2 - очаг некроза, 3 - фиброз ткани собственной пластинки слизистой оболочки, 4 - геморрагический инфильтрат, 5 - лимфоцитарный инфильтрат 


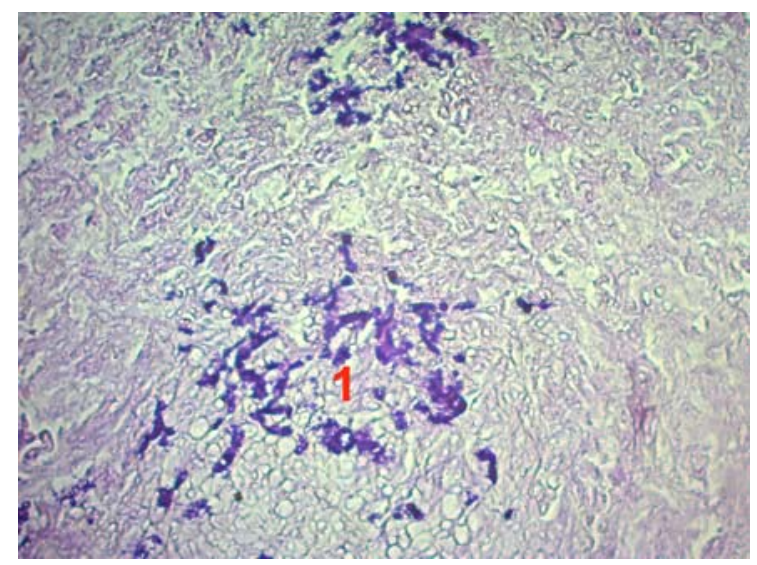

Рис. 2. Гистологический препарат слизистой оболочки гайморовой пазухи пациентки с хроническим ятрогенным гайморитом и герметиком в синусе. Окраска по способу Грам-Вейгерта в модификации А. А. Боголепова. ок. х10., об. х10.

Колонии грибов в собственной пластинке

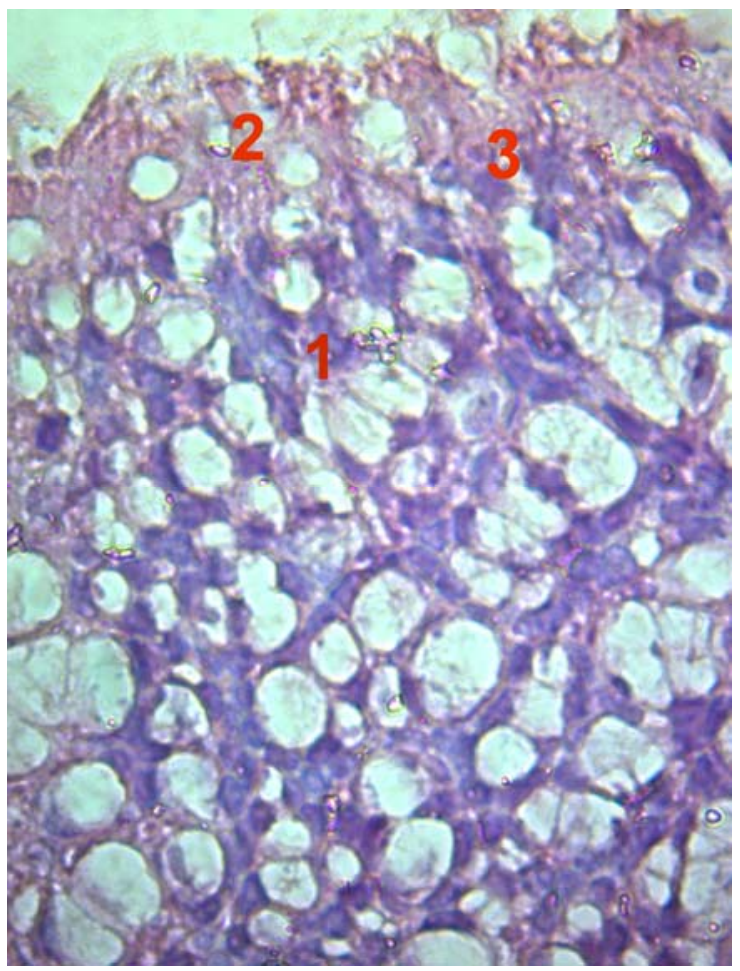

Рис. 3. Метаплазия покровного реснитчатого эпителия гайморовой пазухи больного хроническим одонтогенным гайморитом, вызванным инородным телом (корень зуба). Окраска гематоксилином и эозином. Ок.х10, об.х100. 1 - вакуолизация цитоплазмы эпителиоцитов, 2 - десквамация эпителия, 3 - внутриэпителиальный лимфоцит

\section{5. Обсуждение подученных результатов}

По данным литературы при хроническом одонтогенном гайморите микробная флора верхнечелюстных синусов в основном представлена смешанной или анаэробной флорой [34]. Аэробные ассоциации больше высеиваются из полости носа, а обнаружение большинства микроорганизмов при неодонтогенном гайморите в составе ассоциаций объясняется назальным путем внедрения инфекции

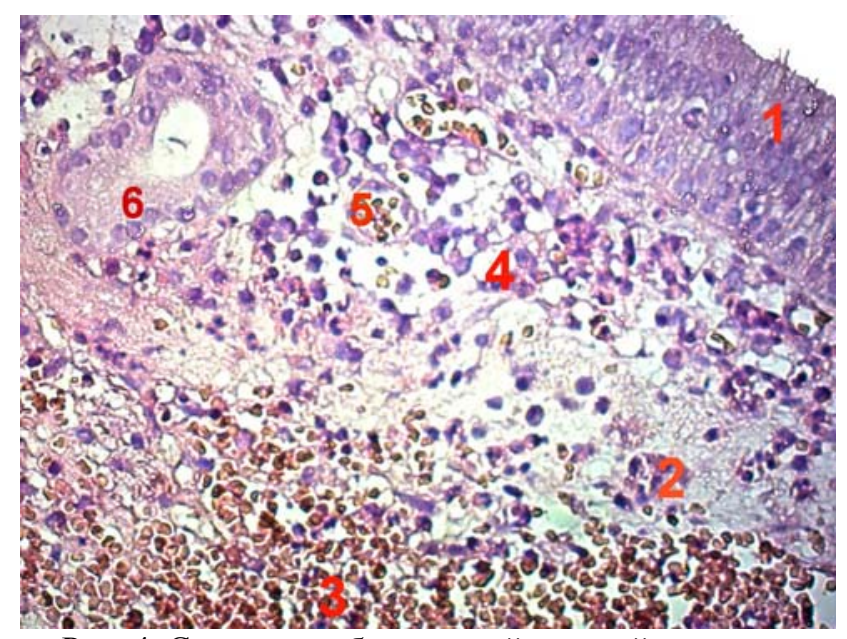

Рис. 4. Слизистая оболочка гайморовой пазухи

больного хроническим ятрогенным гайморитом,

вызванным инородным телом (корень зуба).

Окраска гематоксилином и эозином. Ок.х10, об.х10.

1 - утолщение покровного реснитчатого эпителия,

2 - собственная пластинка слизистой оболочки,

3 - обширный геморрагический инфильтрат,

4 - диффузный воспалительный инфильтрат

(лимфоцитарный и эозинофильный),

5 - полнокровная вена собственной пластинки слизистой оболочки, 6 - концевой отдел железы собственной пластинки слизистой оболочки

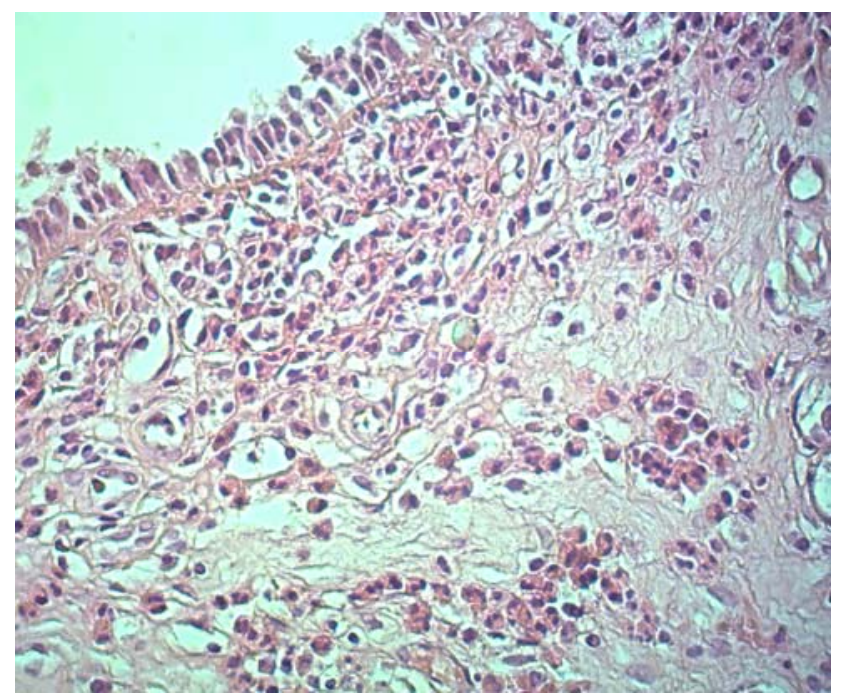

Рис. 5. Слизистая оболочка гайморовой пазухи

больного хроническим ятрогенным гайморитом, вызванным инородным телом (имплантат). Окраска гематоксилином и эозином. Ок. х10, об.х10. Атрофия покровного эпителия

[6]. Полученные результаты микробиологического исследования в группе больных с наличием эндогерметика в просвете синуса, можно объяснить не первичной микробной инвазией пазухи, а вторичным ее инфицированием из полости носа вследствие понижения местных защитных механизмов слизистой оболочки. Иммунодефицитное состояние внутри синуса может быть спровоцировано деструкцией (некрозом) слизистой оболочки хими- 
чески активными составляющими пломбировочного материала, что подтверждается в научных экспериментах [35].

Факультативный анаэроб, сапрофит полости рта - Streptococcus intermedius как правило, связан с гнойными инфекциями и образованием абсцессов [36, 37]. Антимикробная защита слизистых оболочек усилена сложноорганизованной лимфоидной тканью, ассоциированной со слизистой (MALT, MucosaAssociated Lymphoid Tissue), которая богата иммунокомпетентными клетками, координирующими функции иммунной системы [38]. При отсутствии клинических симптомов болезни присутствие вышеописанных микроорганизмов не требует специальной терапии [31]. Однако, с учетом степени микробной обсемененности $\left(10^{8}\right.$ КОЕ/тампон $)$ верхнечелюстных синусов, необходимо хирургическое вмешательство для извлечения эндогерметика проводить с назначением пациенту антибактериальной терапии в лечебных дозах [39]. Анализируя патоморфологическую картину слизистой оболочки верхнечелюстного синуса при хроническом воспалении и наличии в пазухе пломбировочного материала, мы рекомендуем операцию извлечения пломбировочного материала из пазухи проводить с иссечением слизистой оболочки (некротизированной) вокруг инородного тело, с обязательным проведением противогрибковой терапии и гистологического обследования клинического материала.

Кондрашев П. А. (2010) отмечает, что доминирующими возбудителями хронического одонтогенного верхнечелюстного синусита являются представители анаэробной флоры, которые при данной патологии выделяются значительно чаще [40]. Полученное разнообразие микроорганизмов, а также характер морфологических изменений (метаплазия, утолщение), обнаруженных в верхнечелюстных синусах пациентов с протолкнутым корнем в просвете гайморовой пазухи указывает на давность воспалительного процесса в синусе (более 3 мес.) [41, 42]. Учитывая раннюю обращаемость в стационар пациентов с незаконченной экстракцией зуба и корнем протолкнутым в просвет синуса [43], можно предположить, что вышеописанные патологических изменения в строении мембраны гайморовой пазухи возникли задолго до момента удаления «причинного» зуба (удаление зуба по поводу уже имеющегося хронического или обострения хронического одонтогенного гайморита).

Исходя из особенностей микробного состава и степени обсемененности (10 5 КОЕ/тампон) гайморовых пазух, хирургические вмешательства на верхнечелюстном синусе по поводу извлечения корня зуба необходимо «прикрывать» препаратами широкого антибактериального спектра действия (на анаэробную и на аэробную флору) в средних терапевтических дозах. При необходимости дозу антибиотика можно уменьшить до профилактической. При извлечении корня зуба необходим тщательный визуальный анализ состояния пазухи с удалением максимально большого участка измененной слизистой с последующим гистологическим исследованием.

Низкая обсемененность гайморовых пазух при наличии в ней дентального имплантата позволяет, при отсутствии клинической симптоматики воспаления, извлечение имплантата из синуса проводить без назначения антибактериальной терапии. Кроме того считается, что синусит вызванный M. catarrhalis, чаще имеет легкое течение и высокую тенденцию к саморазрешению [44]. Данное положение особенно важно при наличии медикаментозной непереносимости у больного. Патоморфологическая картина (атрофия) слизистой оболочки у пациентов с имплантатом в синусе позволяет, при отсутствии видимых изменений (полип, и грануляции) мембраны Шнайдера, извлечение инородного тела из синуса проводить максимально щадяще, без удаления слизистой оболочки.

\section{6. Выводы}

1. Характер патологических изменений слизистой оболочки верхнечелюстного синуса в значительной степени определяется длительностью течения этих изменений, а также характером и природой инородного тела в просвете пазухи.

2. Наиболее глубокие патологические изменения мембраны гайморовой пазухи выявлены у больных хроническим или обострением хронического одонтогенного гайморита при незаконченном удалении «причинных» зубов.

3. При хроническом ятрогенном гайморите с наличием пломбировочного материала (корневой герметик) в синусе микробная обсемененность в среднем составляет $10^{8} \mathrm{KOE} /$ тампон, преобладают ассоциации аэробов с доминированием Streptococcaceae (44,5\%), выявляется фиброз (в $91 \%$ случаев), некроз (82\%) и колонии грибов (36\%) в слизистой оболочке. Лечение данной группы больных предполагает назначение лечебных доз антибактериальных препаратов, действующих в основном на аэробную флору, противогрибковую терапию, частичное удаление, окружающей инородное тело, некротизированной слизистой оболочки.

4. При хроническом одонтогенном гайморите с наличием корня зуба в синусе микробная обсемененность в среднем составляет $10^{5} \mathrm{KOE/там-}$ пон, преобладают смешанные ассоциации с доминированием бактерий рода Staphilococcaceae $(41,7 \%)$, выявляется метаплазия (50\%) и утолщение $(66,7 \%)$ мембраны Шнайдера. Лечение данной группы больных предполагает назначение антибактериальных препаратов широкого спектра действия в профилактических дозах, удаление максимально большого участка измененной слизистой оболочки.

5. При хроническом ятрогенном гайморите с дентальным имплантатом в синусе микробная обсемененность в среднем составляет $10^{3} \mathrm{KOE} /$ тампон, преобладают монокультуры аэробов с доминированием бактерий рода Moraxella (100\%), выявляется атрофия (100\%) слизистой оболочки. При необходимости извлечение инородного тела из пазухи 
у пациентов данной группы можно проводить без назначения антибактериальных средств, и удаления слизистой оболочки гайморовой пазухи.

\section{Литература}

1. Губайдуллина, Е. А. К методике оперативного вскрытия свищей гайморовой пазухи [Текст] / Е. А. Губайдуллина // Стоматология. - 1959. - №1. - С. 49-55.

2. Бернадский, Ю. И. Одонтогенные гаймориты [Текст] / Ю. И. Бернадский, Н. И. Заславский. - М.: Медицина, 1968. - 134 с.

3. Пискунов, С. З. Щадящее хирургическое лечение одонтогенных гайморитов [Текст] / С. 3. Пискунов, Т. Г. Быканова // Российская ринология. - 1999. - № 4. C. $15-17$.

4. Быканова, Т. Г. Консервативное и хирургическое лечение одонтогенных верхнечелюстных синуситов [Текст]: автореф. дис... канд. мед. наук по спец. 14.00.04 «Болезни ухо, горла и носа» / Т. Г. Быканова. - Курск, 2002. - 22 с.

5. Lopatin, A. S. Chronic maxillary sinusitis of dental origin: Is external surgical approach mandatory? [Text] / A. S. Lopatin, S. P. Sysolyatin, P. G. Sisolyatin, M. N. Melnikov // The Laryngoscope. - 2002. - Vol. 112, Issue 6. - P. 1056-1059. doi: 10.1097/00005537-200206000-00022

6. Закариева, А. Н. Этиологические и патогенетические особенности внебольничного и госпитального синусита [Текст]: автореф. дис... канд. мед. наук по спец. 14.01.03 «Болезни уха, горла и носа»/ А. Н. Закариева. - Москва, 2010. - 24 с.

7. Шульман, Ф. И. Клинико-морфологическое обоснование методов лечения верхнечелюстного синусита, возникшего после эндодонтического лечения зубов [Текст]: автореф. дис... канд. мед. наук по спец. 14.01.14. «Стоматология» / Ф. И. Шульман. - СПб., 2003. - 13 с.

8. Лопатин, А. С. Принципы лечения острых и хронических синуситов [Текст] / А. С. Лопатин // Фармакотерапия болезней уха, горла и носа с позиций доказательной медицины. Лекционный образовательный курс. $-2006 .-$ С. 15-23.

9. Локтионов, В. В. Диагностика, лечение и профилактика верхнечелюстных синуситов, возникающих после эндодонтических вмешательств [Текст]: автореф. дис... канд. мед. наук по спец. 14.01.14. «Стоматология»/ В. В. Локтионов. - Воронеж, 2008. - 24 с.

10. Владыченкова, Н. Д. Анализ врачебных ошибок и осложнений при лечении стоматологических больных (клинико-правовые аспекты проблемы) [Текст]: автореф. дис. ... канд. мед. наук по спец. 14.01.14 «Стоматология»/ Н. Д. Владыченкова. - Смоленск, 2010 - 153 с.

11. Гулюк, А. Г. Динамика обращаемости больных, особенности первичной диагностики и тактика лечения одонтогенных гайморитов [Текст] / А. Г. Гулюк, С. Д. Варжапетян // Вісник стоматології. - 2012. - № 2. - С. 81-89.

12. Мануйлов, О. Е. Стоматогенные гаймориты, клиника и лечение [Текст] / О. Е. Мануйлов, В. С. Агапов, М. Г. Панин // Тезисы 4-го всероссийского съезда оториноларингологов. - Горький, 1978. - С. 325-328.

13. Пухлик, С. М. Хронические экссудативные синуситы [Текст] / С. М. Пухлик // Клиническая иммунология. Аллергология. Инфектология. - 2006. № 2. - C. 14-15.

14. Шмелева, Н. В. Варианты консервативного и хирургического лечения хронических синуситов [Текст]: автор. дисс. ... к. мед. наук по спец. 14.00.04 «Болезни ухо, горла и носа» / Н. В. Шмелева - Спб, 2009. - 20 с.

15. Афанасьева, В. В. Хирургическая стоматология [Текст]: учебник / под общ. ред. В. В. Афанасьев. - М.: ГЭОТАР-Медиа, 2011. - 880 с.
16. Рымша, М. А. Клинический патоморфоз синусита под влиянием атмосферных экологических факторов [Текст]: тезисы 17 съезда оториноларингологов / М. А. Рымша, С. В. Тимошенко, В. А. Чаукина // Материалы XVII съезда оториноларингологов России. - СПб, 2006. - С. 336.

17. Рязанцев, С. В. Принципы этиопатогенетической терапии острых синуситов: Метод, рекомендации [Текст] / С. В. Рязанцев, Н. Н. Науменко, Г. П. Захарова. - СПб. : Национальный регистр, 2007. - 40 с.

18. Иванова, Л. А. Частота встречаемости неблагоприятных факторов и стоматологический статус у пациентов с дисбиозом полости рта [Текст] / Л. А. Иванова, Т. Л. Редипова, А. Б. Черединкова // Институт стоматологии. - 2009. - № 1. - С. 74-75.

19. Сысолятин, С. П. Одонтогенный верхнечелюстной синусит: вопросы этиологии [Текст] / C. П. Сысолятин // Вопросы челюстно-лицевой, пластической хирургии, имплантологии и клинической стоматологии. - 2010. - № 2,3. - С. 3-6.

20. Dutsch-Wicherek, M. Morphology and microanalysis of ectopic tooth removed from maxillary sinus [Text] / M. Dutsch-Wicherek, R. Pawlicki, P. Muszyński, Z. Knychalska-Karwan // Dental and Medical Problems. - 2010. - Vol. 47, Issue 2. -P. 245-250

21. Scattarella, A. Treatment of oroantral fistula with autologous bone graft and application of a non-reabsorbable membrane [Text] / A. Scattarella, A. Ballini, F. R. Grassi et al. // International Journal of Medical Sciences. - 2010. - Vol. 7, Issue 5. - P. 267-271. doi: 10.7150/ijms.7.267

22. Kim, J. W. Chronic maxillary sinusitis caused by root canal overfilling of Calcipex II [Text] / J. W. Kim, K. M. Cho, S. H. Park, S. R. Park, S. S. Lee, S. K. Lee // Restorative Dentistry \& Endodontics. - 2014. - Vol. 39, Issue 1. - P. 63-67. doi: 10.5395/rde.2014.39.1.63

23. Fusetti, S. Chronic oroantral fistula: combined endoscopic and intraoral approach under local anesthesia [Text] / S. Fusetti, E. Emanuelli, C. Ghirotto, G. Bettini, G. Ferronato // American Journal of Otolaryngology. - 2013. - Vol. 34, Issue 4. - P. 323-326. doi: 10.1016/j.amjoto.2012.12.015

24. Мареев, О. В. Анализ хирургических методик лечения одонтогенных верхнечелюстных синуситов, вызванных попаданием в пазуху инородных тел [Электронный ресурс] / О. В. Мареев, А. В. Лепилин, И. П. Коваленко, Г. О. Мареев // Современные проблемы науки и образования. - 2012. - № 5. - Режим доступа: www.science-education.ru/105-7075

25. Fusetti, S. Maxillary sinusitis of dental origin due to oroantral fistula, treated by endoscopic sinus surgery and primary fistula closure [Text] / S. Fusetti, E. Emanuelli, C. Ghirotto, G. Bettini, G. Ferronato // American Journal of Otolaryngology. - 2013. - Vol. 34. - P. 323-326.

26. Andric, M. Endoscopic functional surgery as an adjunct therapy to close oroantral fistula: a retrospective analysis [Text] / M. Andric, V. Saranovic, R. Drazic, B. Brkovic, L. Todorovic // Oral Surgery, Oral Medicine, Oral Pathology, Oral Radiology, and Endodontology. - 2010. - Vol. 109, Issue 4. - P. 510-516. doi: 10.1016/j.tripleo.2009.10.028

27. Nair, U. P. Maxillary sinusitis of odontogenic origin: cone-beam volumetric computerized tomography-aided diagnosis [Text] / U. P. Nair, M. K. Nair // Oral Surgery, Oral Medicine, Oral Pathology, Oral Radiology, and Endodontology. - 2010. - Vol. 110, Issue 6. - P. 53-57. doi: $10.1016 /$ j.tripleo.2010.06.020

28. Chen, Y. W. The characteristics and new treatment paradigm of dental implant-related chronic rhinosinusitis [Text] / Y. W. Chen, C. C. Huang, P. H. Chang, C. W. Chen, C. C. Wu, C. H. Fu, T.-J. Lee // American Journal of Rhinology and Allergy. -2013. - Vol. 27, Issue 3. - P. 237-244. doi: 10.2500/ajra.2013.27.3884 
29. Шелковая, Н. Г. Метод количественного исследования содержания бактерий в клинических материалах, отобранных с помощью ватного тампона [Текст]: сб. наук. Трудов сотрудников КМАПО / Н. Г. Шелковая, В. П. Прокопец - Киев, 2008. - Вып. 17. - С. 698-702.

30. Зеленова, Е. Г. Микрофлора полости рта: норма и патология [Текст] / Е. Г. Зеленова, М. И. Заславская, Е. В. Салипа, С. П. Рассанов. - Н. Новгород : НГМА, 2004. $158 \mathrm{c}$.

31. Захаров, А. А. Анализ микрофлоры ротовой полости обследованных людей с различными заболеваниями [Текст] / А. А. Захаров, Н. А. Ильна // Успехи современного естествознания. - 2007. - № 12 C. $141-143$.

32. Туровский, А. Б. Лечение и меры профилактики рецидивирующего бактериального синусита [Текст]: автореф. дис.... док. мед. наук. по спец. 14.00.04 «Болезни уха, горла и носа» / А. Б. Туровский. - М., $2009-36$ с.

33. Небыльцова, О. В. Лабораторный справочник СИНЭВО [Текст] / О. В. Небыльцова, Ж. А. Климова, Г. А. Носенко, И. В. Бойко, и др.; под ред. О. В. Небыльцовой. - К.: ООО «Доктор Медиа», 2011. - 420 с.

34. Иванова, М. А. Лечение рецидивирующих воспалительных заболеваний полости носа и околоносовых пазух [Текст]: автореф. дис... канд. мед. наук по спец.14.00.04. «Болезни уха, горла и носа» / М. А. Иванова. - M., 2008. - 24 c.

35. Бабов, Є. Д. Вплив сучасних ендогерметиків на мікрофлору періапікальних тканин при лікуванні хронічного періодонтиту зубів верхньої щелепи [Текст] / Є. Д. Бабов, Н. Ф. Біла, С. Д. Варжапетян, О. О. Фаренюк // Одеський медичний журнал. - 2013. - № 3 (137). - С. 62-65.

36. Salavert, M. I. Seven-year review of bacteremia caused by Streptococcus milleri and other viridans streptococci [Text] / M. I. Salavert, L. Gómez, M. Rodriguez-Carballeira, M. Xercavins, N. Freixas, J. Garau // European Journal of Clinical Microbiology \& Infectious Diseases. - 1996. - Vol. 15, Issue 5. - P. 365-371. doi: 10.1007/bf01690091

37. Murray, H. W. Serious infections caused by Streptococcus milleri [Text] / H. W. Murray, K. C. Gross, H. Masur, R. B. Roberts // The American Journal of Medicine. 1978. - Vol. 64, Issue 5. - P. 759-764. doi: 10.1016/00029343(78)90555-7

38. Тюрин, Ю. А. Природная устойчивость бактерий к факторам вражденной иммунной системы, обусловленная бактериальными протеазами [Текст] / Ю. А. Тюрин, И. Г. Мустафин, Р. С. Фассанов // Лекции для практикующих врачей. - 2010. - № 1-С. 7-13.

39. Рекалова, Е. М. Условнопатогенная микрофлора при неспецифических заболеваниях легких [Текст] / Е. М. Рекалова // Український пульмонологічний журнал. 2003. - № 3 - С. $65-69$.

40. Кондрашев, П. А. Микробиологический спектр возбудителей риногенного и одонтогенного хронического синусита и мукоцилиарная активность эпителия слизистой оболочки полости носа [Текст] / П. А. Кондрашев, О. Е. Лодочкина, О. Н. Опрышко // Вестник оториноларингологии. - 2010. - № 4. - С. 45-47.

41. Иванов, Ю. В. Состояние слизистой оболочки верхнечелюстного синуса у больных с ороантральным сообщением в разные сроки после его возникновения [Текст] / Ю. В Иванов, К. В. Федосенко, И. Н. Калакуцкий // Стоматология. - 2006. - № 6. - С. 51-54.

42. Гулюк, А. Г. Морфологические изменения слизистой оболочки верхнечелюстной пазухи при различных формах хронического однтогенного гайморита (часть I) [Текст] / А. Г. Гулюк, С. Д. Варжапетян, Е. А. Григорьева, А. А. Фурик // Современная стоматология. - 2013. - № 4(68) - C. 131-136.
43. Taxy, J. B. Paranasal Fungal Sinusitis: Contribution of Histopatology to Diagnosis. A Report of 60 Cases and Literature Review [Text] / J. B. Taxy // The American Journal of Surgical Pathology. - 2006. - Vol. 30, Issue 6. - P. 713-720. doi: 10.1097/00000478-200606000-00006

44. Лопатин, А. С. Острый риносинусит: этиология, патогенез, диагностика и принципы лечения [Электронный pecypc] / А. С. Лопатин, В. М. Свистушкин. - Клинические рекомендации. М., 2009. - 3 с. - Режим доступа: http://medi.ru/doc/270116.htm

\section{References}

1. Gubaidullina, E. A. (1959). K metodike operativnogho vskritiya svishey haymorovoy pazukhi [On the methods of surgical dissection of the maxillary sinus fistula]. Stomatolohyya, 1, 49-55.

2. Bernadsky, Yu. I., Zaslavsky N. I. (1968). Odontohennie haymoryti [Odontogenic sinusitis]. Moscow: Medicine, 134.

3. Piskunov, S. Z., Bykanova, T. G. (1999). Schadyaschee hyrurhycheskoe lecheniye odontohenikh haymorytov [Protective surgical treatment of odontogenic sinusitis]. Ros. Rhinology, 4, 15-17.

4. Bykanova, T. G. (2002). Konservatyvnoe i khyrurhycheskoe treatment odontohennikh verkhntchelustnikh sinusitov [Conservative and surgical treatment of odontogenic maxillary sinusitis]. Kursk, 22.

5. Lopatin, A. S., Sysolyatin, S. P., Sysolyatin, P. G., Melnikov, M. N. (2002). Chronic Maxillary Sinusitis of Dental Origin: Is External Surgical Approach Mandatory? The Laryngoscope. Wiley-Blackwell, 112 (6), 1056-1059. doi: 10.1097/00005537-200206000-00022

6. Zakarieva, A. N. (2010). Etiologicheskie i pathogeneticheskie factori vnebolnychnovo I hospytalnovo sinusita [Etiological and pathogenetic features of communityacquired and hospital sinusitis]. Moscow, 24.

7. Shulman, F. I. (2003). [Clinicopathologic study of maxillary sinusitis treatments that emerged after endodontic treatment of teeth]. St. Petersburg, 13/

8. Lopatin, A. S. (2006). Principi lecheniya ostrich i khronicheskikh sinusitov[Principles of treatment of acute and chronic sinusitis] Pharmacotherapy of diseases of the ear, nose and throat from the standpoint of evidence-based medicine. Lecture educational course. Moscow, 15-23.

9. Loktionov, V. V. (2008). Diagnostyca, lecheniye, i profilactica verkhntchelustnikh sinusitov, vaznikaushikh posle endodonticheskikh vmeshatelstv [Diagnosis, treatment and prevention of maxillary sinusitis arising after endodontic treatment]. Voronezh, 24.

10. Vladychenkova, N. D. (2010). Analys vrachebnikh oshybok i oslozhneniy pry lechenii stomatolohycheskykh bolnikh (clinico- pravovie aspecti problemi [Analysis of medical errors and complications in the treatment of dental patients (clinical and legal aspects)]. Smolensk, 153.

11. Gulyuk, A. G., Varzhapetyan, S. D. (2012). Dynamika obrashaemocti, osobenosty pervychnoy diagnostiki i taktyka lecheniya odontogenikh gaymorytov [Dynamics negotiability patients, particularly primary diagnosis and treatment strategy of odontogenic sinusitis]. News stomatologies, 2, 81-89.

12. Manuilov, O. E., Agapov, B. C., Panin, M. G. (1978). Stomatogeniye gaymariti, klinika, lecheniye [Stomatogen maxillary sinusitis, clinic and treatment]. Proceedings of the 4th All-Russian Congress of otorinolaringologov. hitter, 325-328

13. Pukhlik, S. M. (2006). Khronicheskiye ecsudativnye sinusiti [Chronic exudative sinusitis]. Clinical Immunology. Allergology. Infectology, 2, 14-15. 
14. Shmeleva, N. V. (2009). Varianti conservatyvnovo i khirurgichescovo lecheniya khronichescikh sinusitov [Variants of conservative and surgical treatment of chronic sinusitis]. $\mathrm{SPb}, 26$.

15. Afanasiev, V. V. et al. (2011). Oral Surgery: Textbook. Moscow: GEOTAR Media, 880.

16. Rymsha, M. A., Timoshenko, S., Chaukina, V. A. (2006). Clinicheskiy patomorfoz sinusita pod vliyaniyem atmosphernikh ecologicheskikh phactorov [Clinical pathomorphosis sinusitis under the influence of atmospheric environmental factors]: 17 theses Congress otolaryngologists. Proceedings of the XVII Congress of otolaryngologists in Russia. SPb, 336.

17. Ryazantsev, C. B., Naumenko, H. H., Zakharov, G. P. (2007). Printsipy ethyopatogenetichescoy terapiy ostrich synusitov [Principles etiopathogenic therapy of acute sinusitis: Method, recommendations]. Second edition, $\mathrm{SPb}$ : National Register, 40.

18. Ivanova, L. A., Redipova, T. L., Cheredinkova, A. B. (2009). Chastota vstrechaemosty neblahopryyatnikh factorov I stomatolohychesky status patsyentov s dysbiosom polosty rta [Incidence of adverse factors and dental status of patients with oral dysbiosis]. Institute of Dentistry, 1, 74-75.

19. Sysoljatin, S. P. (2010). Odontogennyj verhnecheljustnoj sinusit: voprosy jetiologii [Odontogenic maxillary sinusitis: etiology]. Questions maxillofacial, plastic surgery, implantology and clinical dentistry, 2, 3, 3-6.

20. Dutsch-Wicherek, M., Pawlicki, R., Muszyński, P., Knychalska-Karwan, Z. (2010). Morphology and microanalysis of ectopic tooth removed from maxillary sinus. Dental and Medical Problems, 47 (2), 245-250

21. Scattarella, A., Ballini, A., Grassi, F. R. et al. (2010). Treatment of oroantral fistula with autologous bone graft and application of a non-reabsorbable membrane. International Journal of Medical Sciences, 7 (5), 267-271.

doi: 10.7150/ijms.7.267

22. Kim, J. W., Cho, K. M., Park, S. H., Park, S. R., Lee, S. S., Lee, S. K. (2014). Chronic maxillary sinusitis caused by root canal overfilling of Calcipex II. Restorative Dentistry \& Endodontics, 39 (1), 63-67. doi: 10.5395/rde.2014.39.1.63

23. Fusetti, S., Emanuelli, E., Ghirotto, C., Bettini, G., Ferronato, G. (2013). Chronic oroantral fistula: combined endoscopic and intraoral approach under local anesthesia. American Journal of Otolaryngology, 34 (4), 323-326. doi: 10.1016/j.amjoto.2012.12.015

24. Mareev, O. V., Lepilin, A. V., Kovalenko, I. P., Mareev, G. O. (2012). Analiz hirurgicheskih metodik lechenija odontogennyh verhnecheljustnyh sinusitov, vyzvannyh popadaniem $\mathrm{v}$ pazuhu inorodnyh tel [Analysis of surgical treatment of odontogenic maxillary sinusitis caused by hitting the bosom of foreign bodies]. Modern problems of science and education, 5. Available at: www.science-education.ru/105-7075

25. Fusetti, S., Emanuelli, E., Ghirotto, C., Bettini, G., Ferronato, G. (2013). Maxillary sinusitis of dental origin due to oroantral fistula, treated by endoscopic sinus surgery and primary fistula closure. American Journal of Otolaryngology, 34, 323-326.

26. Andric, M., Saranovic, V., Drazic, R., Brkovic, B., Todorovic, L. (2010). Endoscopic functional surgery as an adjunct therapy to close oroantral fistula: a retrospective analysis. Oral Surgery, Oral Medicine, Oral Pathology, Oral Radiology, and Endodontology, 109 (4), 510-516.

doi: 10.1016/j.tripleo.2009.10.028

27. Nair, U. P., Nair, M. K. (2010). Maxillary sinusitis of odontogenic origin: cone-beam volumetric computerized tomography-aided diagnosis. Oral Surgery, Oral Medicine, Oral Pathology, Oral Radiology, and Endodontology, 110 (6), 53-57. doi: $10.1016 /$ j.tripleo.2010.06.020
28. Chen, Y. W., Huang, C. C., Chang, P. H., Chen, C. W., Wu, C. C., Fu C. H., Lee, T.-J. (2013). The characteristics and new treatment paradigm of dental implantrelated chronic rhinosinusitis. American Journal of Rhinology and Allergy, 27 (3), 237-244. doi: 10.2500/ajra.2013.27.3884

29. Shelkovaja, N. G., Prokopec, V. P. (2008). Metod kolichestvennogo issledovanija soderzhanija bakterij $\mathrm{v}$ klinicheskih materialah, otobrannyh s pomoshh'ju vatnogo tampona [Method of quantitative studies of bacteria in clinical specimens taken with a cotton swab]. Kiev, 17, 698-702.

30. Zelenova, E. G., Zaslavskaja, M. I., Salipa, E. V., Rassanov, S. P. (2004). Mikroflora polosti rta: norma i patologija [Oral microflora: norm and pathology]. Novgorod : NGMA, 158.

31. Zaharov, A. A., Il'na, N. A. (2007). Analiz mikroflory rotovoj polosti obsledovannyh ljudej s razlichnymi zabolevanijami [Analysis of the microflora of the oral cavity surveyed people with various diseases]. Successes contemporary science, 12, 141-143.

32. Turovskij, A. B. (2009). Lechenie i mery profilaktiki recidivirujushhego bakterial'nogo sinusita [Treatment and prevention of recurrent bacterial sinusitis]. Moscow, 36 .

33. Nebyl'cova, O. V., Klimova, Zh. A., Nosenko, G. A., Bojko, I. V. et. al.; O. V. Nebyl'cova (Ed.) (2011). Laboratornyj spravochnik SINJeVO [Laboratory reference SYNEVO]. Kiev: OOO «Doktor Media», 420.

34. Ivanova, M. A. (2008). Lechenie recidivirujushhih vospalitel'nyh zabolevanij polosti nosa i okolonosovyh pazuh [Treatment of recurrent inflammatory diseases of the nasal cavity and paranasal sinuses]. Moscow, 24.

35. Babov, Je. D., Bila, N. F., Varzhapetjan, S. D., Farenjuk, O. O. (2013). Vplyv suchasnyh endogermetykiv na mikrofloru periapikal'nyh tkanyn pry likuvanni hronichnogo periodontytu zubiv verhn'oi' shhelepy [The impact of modern endohermetykiv the microflora of periapical tissues in the treatment of chronic periodontitis teeth of the upper jaw]. Odessa Medical Journal, 3 (137), 62-65.

36. Salavert, M. I., Gómez, L., Rodriguez-Carballeira, M., Xercavins, M., Freixas, N., Garau, J. (1996). Seven-year review of bacteremia caused by Streptococcus milleri and other viridans streptococci. European Journal of Clinical Microbiology \& Infectious Diseases, 15 (5), 365-371. doi: 10.1007/bf01690091

37. Murray, H. W., Gross, K. C., Masur, H., Roberts, R. B. (1978). Serious infections caused by Streptococcus milleri. The American Journal of Medicine, 64 (5), 759-764. doi: 10.1016/0002-9343(78)90555-7

38. Tjurin, Ju. A., Mustafin, I. G., Fassanov, R. S. (2010). Prirodnaja ustojchivost' bakterij k faktoram vrazhdennoj immunnoj sistemy, obuslovlennaja bakterial'nymi proteazami [The natural bacterial resistance to factors of the innate immune system caused by bacterial proteases]. Lectures for medical practitioners, 1, 7-13.

39. Rekalova, E. M. (2003). Uslovnopatogennaja mikroflora pri nespecificheskih zabolevanijah legkih [Opportunistic microflora with nonspecific lung diseases]. Ukrainian pulmonological magazine, 3, 65-69.

40. Kondrashev, P. A., Lodochkina, O. E., Opryshko, O. N. (2010). Mikrobiologicheskij spektr vozbuditelej rinogennogo i odontogennogo hronicheskogo sinusita $i$ mukociliarnaja aktivnost' jepitelija slizistoj obolochki polosti nosa [Microbiological spectrum of pathogens rhinogenous and odontogenic chronic sinusitis and mucociliary activity of the epithelium of the nasal mucosa]. Bulletin of otorhinolaryngology, 4, 45-47.

41. Ivanov, Ju. V., Fedosenko, K. V., Kalakuckij, I. N. (2006). Sostojanie slizistoj obolochki verhnecheljustnogo sinusa $\mathrm{u}$ bol'nyh s oroantral'nym soobshheniem v raznye sroki posle ego vozniknovenija [The state of the maxillary sinus mucosa in 
patients with oroantralnym message at different times after its occurrence]. Stomatology, 6, 51-54.

42. Guljuk, A. G., Varzhapetjan, S. D., Grigor'eva, E. A., Furik, A. A. (2013). Morfologicheskie izmenenija slizistoj obolochki verhnecheljustnoj pazuhi pri razlichnyh formah hronicheskogo odntogennogo gajmorita (chast' I) [Morphological changes of the mucous membrane of the maxillary sinus with various forms of chronic sinusitis odntogennogo (Part I)]. Modern Stomatology, 4 (68), 131-136.

43. Taxy, J. B. (2006). Paranasal Fungal Sinusitis: Contribution of Histopatology to Diagnosis. A Report of 60
Cases and Literature Review. The American Journal of Surgical Pathology, 30 (6), 713-720. doi: 10.1097/00000478-20060600000006

44. Lopatin, A. S., Svistushkin, V. M. (2009). Ostryj rinosinusit: jetiologija, patogenez, diagnostika i principy lechenija [Acute rhinosinusitis: etiology, pathogenesis, diagnosis, and treatment guidelines]. Clinical Recommendations. Moscow, 3. Available at http://medi.ru/doc/270116.htm

Дата надходження рукопису 30.11.2014

Гулюк Анатолий Георгиевич, доктор медидинских наук, професор, заведующий кафедрой хирургической стоматологии ОНМУ, заведующий отделом хирургии института стоматологии АМН Украины, ГУ «Институт стоматологи НАМН Украины», отдел хирургической стоматологии, ул. Решельевская, 11, г. Одесса, Украина, 65026

E-mail: agulyuk@list.ru

Варжапетян Сурен Диасович, ассистент кафедры хирургической и терапевтической стоматологии ГЗ «ЗМАПО МЗ Украины», кандидат медицинских наук, ГУ «ГКБЭ и СМП», кафедры хирургической и терапевтической стоматологии, ул. Победы, 80, г. Запорожье, Украина, 69005

E -mail: suren-wargapetyan@,rambler.ru

Тащян Армен Эдуардович, ассистент кафедры хирургической стоматологии ОНМУ, кандидат медицинских наук, ГУ «Институт стоматологи НАМН Украины», отдел хирургической стоматологии, ул. Решельевская, 11, г. Одесса, Украина, 65026 